\title{
Hypopituitarism caused by a melanoma of the pituitary gland
}

\author{
JAMES MCE. NEILSON AND A. D. MOFFAT \\ From the Departments of Medicine and Pathology, Stobhill General Hospital, Glasgow
}

SYNOPSIS A clinical and pathological description is given of a case of panhypopituitarism cause by a melanoma of the pituitary gland. The possible origins of a melanoma in this site are discussed $\vec{\sigma}$

Neoplastic causes of hypopituitarism may be classified into three groups: 1 , Primary tumours of the pituitary gland (chromophobe adenoma, malignant chromophobe adenoma (carcinoma of the pituitary), craniopharyngioma (adamantinoma, ameloblastoma, Rathke's pouch tumour, suprasellar cyst, teratoma, tumour of the hypophyseal duct)); 2 , tumours of closely related structures (meningioma, carcinoma of the nasopharynx, tumours of the third ventricle, glioma of the optic nerve and chiasma, parapituitary epidermoid and dermoid tumours); 3 , metastatic carcinoma.

\section{CASE REPORT}

The patient was aged 62 when he first attended the Haematology Clinic in August 1956. Since 1946 he had complained of symptoms of rheumatoid arthritis affecting chiefly both wrists, the joints of both hands, both knees, and the left shoulder. He had been a miner for more than 30 years when, in 1949, he was awarded a $40 \%$ pension for coal-miner's pneumoconiosis. On admission to the ward on 15 August 1956 his major complaints were of chronic dyspnoea related to pneumoconiosis and of a recent exacerbation in the rheumatoid arthritis. He had not at any time noticed tiredness or weakness but for approximately 10 years he had observed that he required to shave less frequently and that his body hair had decreased. Oral iron therapy had been prescribed by his own doctor because of pallor of the skin. The patient had failed to note any recent increase in pallor and claimed that he had always been pale. His wife had had five children, four of whom were alive and well in 1956. The youngest was aged 20 years.

The patient looked older than his stated age. The skin and mucosae showed some pallor, and the former was very fine and soft. Changes attributable to rheumatoid arthritis affected the joints previously mentioned. His nails were beaked. There was slight bilateral ankle oedema. Suprapubic, axillary, and beard-area hair was

Received for publication 17 September 1962 very sparse. The hair on the scalp was thin but evenly distributed. The external genitalia were normal in? appearance. The tongue was reddened and showed atrophy of the mucosa along the middle of the dorsum The pulse rate was 60 per minute and the rhythm was regular. There was no cardiac enlargement. The heart sounds were faint but clear-cut. His blood pressure wase $120 / 70 \mathrm{~mm}$. of mercury. There was clinical evidence ofe pulmonary emphysema. The percussion note was im paired at the left base posteriorly and the respiratoryo murmur was reduced over the same area. There were nos neurological abnormalities. In particular, the ocularo fundi were normal and perimetry showed no visua field defect.

His I.Q. was not of a high order.

Haemoglobin was $11.9 \mathrm{~g}$. per $100 \mathrm{ml}$., the M.C.H.C. $31 \cdot 3 \%$. The sternal marrow was relatively hypoplastic but erythropoiesis was normoblastic. Basal metabolic rates on two occasions were $-10 \%$ and $-6 \%$ of standard: The serum urea estimated on several occasions was withing normal limits. Serum electrolytes, apart from slight:hyponatraemia, were also within normal limits. A chest 3 . radiograph showed an opacity at the left base suggestiven of pneumonia with an associated small pleural effusion. There were no diagnostic features of pneumoconiosis. Radiological changes of rheumatoid arthritis were presento in both knees. After a preliminary few days of a high $>$ carbohydrate diet a $50 \mathrm{~g}$. oral glucose tolerance test? showed a flat curve beginning with a fasting level of $78 \mathrm{mg} . \%$ and rising to $124 \mathrm{mg} . \%$ one hour later. At the end of two hours the blood sugar dropped to $74 \mathrm{mg} . \%$. N An intravenous glucose tolerance test showed norman maximal values but the blood sugar at 120 minutes was $\mathrm{\omega}$ only $57 \mathrm{mg}$. \%. An intravenous insulin sensitivity test was not performed but the blood sugar after an oral dose을 of $1.0 \mathrm{~g}$. of carbutamide fell to hypoglycaemic levels and历్ remained there for six hours. A 24-hour urine volume? of $1,140 \mathrm{ml}$. contained only $0.47 \mathrm{mg}$. of 17 -ketosteroids. A skull radiograph showed enlargement of the sella. turcica with erosion of the posterior clinoid processes. The Wassermann and Kahn reactions were both negative. $\frac{\text { ते }}{\mathrm{s}}$

These features were sufficient to establish the diagnosis of pneumonia, rheumatoid arthritis, and hypopituitarism. 
He was seen by a neurosurgeon who thought that the likeliest cause of the last condition was a chromophobe adenoma although a Rathke pouch tumour was another possibility.

The patient was given soluble aspirin for rheumatoid arthritis and the pneumonia was treated with penicillin. The hypopituitarism was treated with monthly intramuscular injections of methyl testosterone microcrystules (100 mg.), oral thyroid (60 mg. per day), and cortisone (25 mg. per day). He was discharged in October of the same year subjectively and objectively much improved.

He was kept under review at intervals as an outpatient but in March 1957 had to be readmitted. In January of 1957 he had been treated for a recurrence of pneumonia in another hospital where, apparently, supportive endocrine therapy had been discontinued. When this was re-instituted his symptoms disappeared and he returned to good health. He was discharged on 22 March 1957.

He attended as an out-patient for a further seven months remaining on the therapy noted above. In addition, on several occasions he was given intra-articular hydrocortisone into both knee joints.

In April 1958 he gave a history of an episode of severe anterior chest pain some five weeks previously. An E.C.G. showed evidence of minimal restricted anterior myocardial damage, and a chest radiograph showed some cardiac enlargement. A skull radiograph showed no change in the appearance of the sella turcica. He was not admitted. For more than a year thereafter he was comparatively well although requiring repeated intraarticular trimethyl prednisolone for rheumatoid arthritis.

On 27 July 1959 he was readmitted for the last time. Before admission he had been complaining of marked frequency and his general practitioner had prescribed sulphadiazine for cystitis. The patient, afraid of confusing the various tablets he was receiving, decided to discontinue thyroid and cortisone. Four days after he did so, probably as a consequence of the combined effect of the urinary tract infection and the withdrawal of replacement endocrine therapy, he became semi-comatose and was admitted to hospital. His blood pressure was $85 / 65 \mathrm{~mm}$. of mercury. A chest radiograph showed generalized cardiac enlargement with some pulmonary congestion, and an E.C.G. evidence of anterior and posterior ischaemic myocardial damage. The serum urea was $27 \mathrm{mg} . \%$, serum protein $6.3 \mathrm{~g} . \%$, serum chloride $91 \mathrm{mEq}$./litre, serum sodium $120 \mathrm{mEq}$./litre, potassium $4.0 \mathrm{mEq}$./litre, and alkali reserve $17 \mathrm{mEq}$./litre. Pus cells were still present in the urine and culture produced a growth of $B$. coli. Initially he responded well to treatment for pyuria and to an increased dosage of cortisone but on 8 August he suddenly became dyspnoeic and lapsed into coma with an unrecordable pulse or blood pressure. He died shortly afterwards.

\section{NECROPSY}

There was rheumatoid deformity of the joints previously indicated. The features of chronic bronchitis and emphysema with early cor pulmonale were

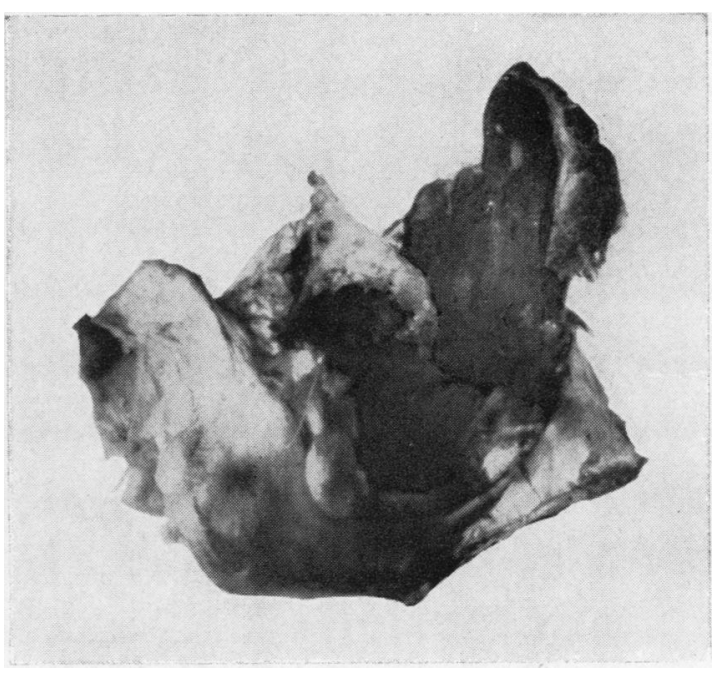

FIG. 1. Pituitary gland and adjacent part of sphenoid. A block has been removed from the middle of the gland. Natural size.

present. There was no histological evidence of pneumoconiosis. The coronary arteries were atheromatous with moderate encroachment on their lumina but no evidence of myocardial fibrosis was found. There was benign hyperplasia of the prostate. The urinary bladder was moderately distended but there was no evidence of pyogenic infection in the urinary tract.

The pituitary gland was grossly enlarged $(3.5 \times$ $3 \times 2.5 \mathrm{~cm}$.) and jet-black throughout (Fig. 1) except for a thin rind of whitish tissue on the right postero-lateral aspect. The enlarged gland had eroded the bony floor of the sella turcica which was represented by a thick, tough, fibrous membrane. The diaphragma sellae did not appear to be infiltrated but was displaced upwards to impinge upon and erode the surface of the medial aspect of the left optic tract. There was no evidence of pigmentation or tumour in the eyeballs, optic nerves, tracts, or meninges. A careful search of the suprarenals, nails, and skin also failed to show a primary growth.

\section{HISTOLOGY OF THE PITUITARY GLAND}

Step sections were examined from a series of blocks representing the entire pituitary gland and this description is a summary of the findings.

The whitish rind of tissue on the right posterolateral aspect of the gland was found to consist of pars nervosa and somewhat atrophic anterior pituitary lobe tissue with intercellular fibrosis. A small non-encapsulated chromophobe adenoma, 
TABLE

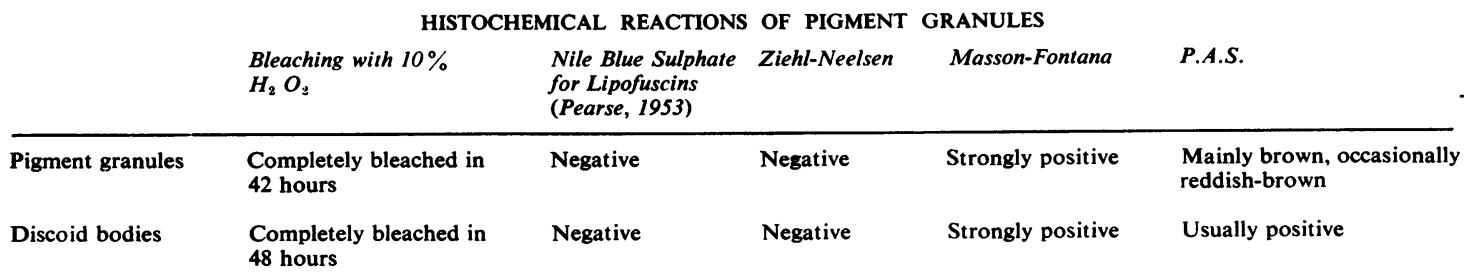

$1 \mathrm{~mm}$. in diameter, lay within the anterior lobe tissue. The cells of this adenoma were mainly small and rounded with scanty cytoplasm (Fig. 2), but in some parts the cells had a larger proportion of cytoplasm. A few of both types of cells contained dark pigment granules (Fig. 3), whilst some of the cells in the atrophic anterior pituitary tissue also contained similar granules of pigment. The mass of black tissue showed an adenomatous pattern (Fig. 4) although areas of more papilliform structure were seen. In some areas both patterns intermingled (Fig. 5). The cellular detail was usually completely obscured by a heavy deposit of dark brown coarse and fine granules which seemed to distend the cells, many of which appeared to be ruptured so that the pigment was extruded into the intercellular spaces. Elsewhere most of the cells were rounded and often contained dark, brownish, structureless, discoid bodies (Fig. 6) but sometimes they were columnar or even triangular. Occasionally, there were islets of smaller rounded cells with scanty cytoplasm lightly pigmented with fine brown granules (Fig. 5).

Pigmented tumour tissue had penetrated the capsular lymphatics of the pituitary (Fig. 4) and the pars nervosa (Fig. 7).

The histochemical reactions given by the pigment granules and the intracellular discoid bodies are summarized in the Table and show conclusively that the pigment in both instances was melanin. A few small deposits of brown pigment around some of the blood vessels gave negative results in all the above tests but a positive Perls' iron-staining reaction.

\section{DISCUSSION}

A search of the literature shows that a melanincontaining tumour of the pituitary gland has only once before been reported. This was a secondary melanoma mentioned by Biggart (1961). The site of the primary growth was not recorded nor was it noted whether the tumour was a single secondary or only one of multiple deposits. In the present case two different tumours were found in the pituitary. The larger tumour was heavily pigmented with melanin. The smaller showed the features of a chromophobe adenoma with occasional cells which contained melanin. Examination of step sections $\vec{\omega}$ showed that the two tumours were always separated by anterior lobe tissue with no continuity between? them. It is recognized that pituitary adenomata are $\vec{\sigma}$ common, and estimates vary between $8 \%$ and $10 \%$ in routine necropsies (Kraus quoted by Anderson, $\vec{A}$ 1953; Biggart and Dott, 1936). The chromophobe type is the most common (Anderson, 1953). The 5 small adenoma $(1 \mathrm{~mm}$. in diameter) may therefore $\overrightarrow{-}$ be regarded as an incidental finding only. Before it is dismissed, however, it should be noted that, although melanin pigmentation was extreme in the larger $\overrightarrow{.}$ tumour, a few cells of the small adenoma also con- $\mathscr{\odot}$ tained melanin granules. Melanosis and melanomata may occur in sites where normally no melanin is formed (Willis, 1959), and, since melanin pigmentation was common to both tumours, it is possible that they were variants of the same growth, the chromophobe being the cell type unrecognizable $\stackrel{\odot}{\mathscr{}}$ in the larger tumour because of extensive melanosis. $\overrightarrow{\vec{B}}$ The more plausible explanation, however, is that 3 these were distinct and separate lesions, the larger tumour being a true melanoma.

It has already been emphasized that a careful post-mortem search of the usual sites of primary? melanomata was unrewarding. Although the eyeballs were not opened at necropsy, they were examined frequently and carefully during the three $\frac{\mathrm{O}}{3}$ years the patient was under observation and on several occasions in the days immediately preceding his death without showing any evidence of a $\frac{7}{0}$ melanoma. In addition the optic nerves, optic tracts, and suprarenals showed no tumour tissue. $N$ The possibility cannot be excluded that the patient $\mathrm{N}$ might have had a melanoma removed from the skin 오 years before his death but there were no obvious $\omega$ scars to suggest this. The onset of symptoms due to hypopituitarism cannot be dated accurately but it can be accepted that this state was present for three years before death. The fact that the tumour was:present for this duration of time and remained $\frac{T}{\circ}$ solitary makes it seem improbable that it was $a \underset{\mathbb{D}}{ }$ metastatic growth.

Primary melanomata of the leptomeninges have $\stackrel{\mathbb{Q}}{\circ}$ been described (Gibson, Burrows, and Weir, 1957; 


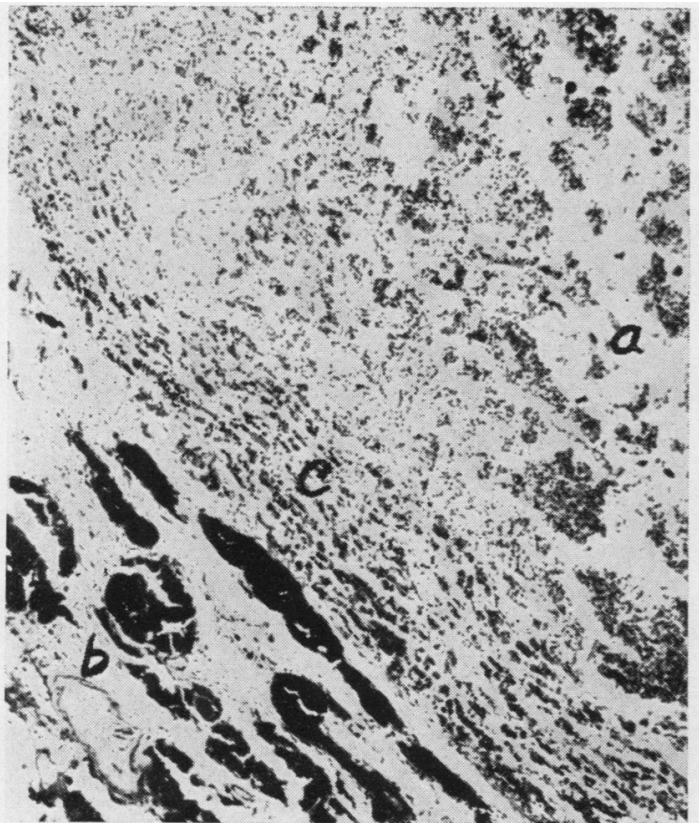

FIG. 2

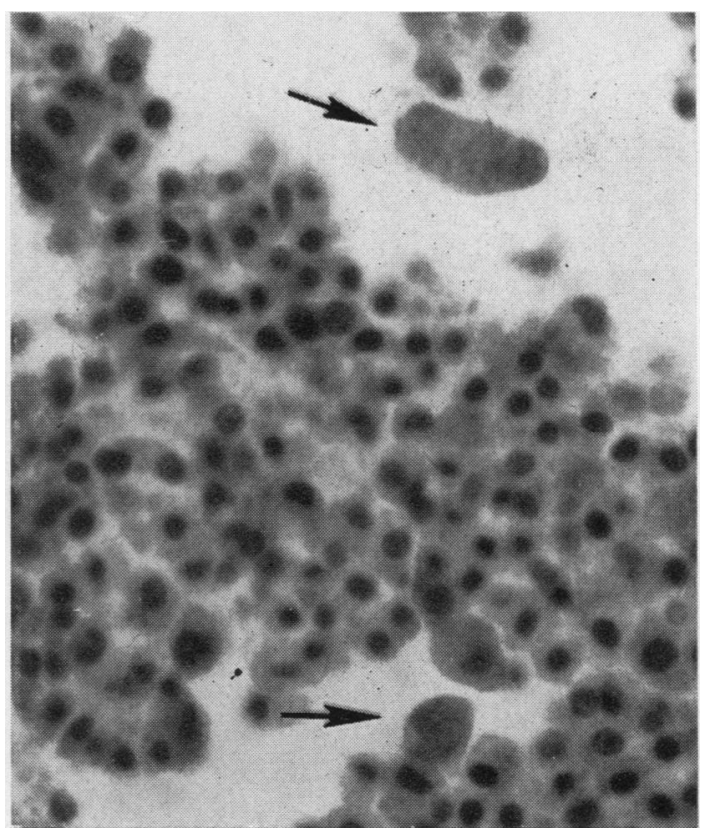

FIG. 3

FIG. 4. Adenomatous pattern of pigmented tumour and penetration of capsular lymphatic. Masson-Fontana $\times 50$. FIG. 5. Adenomatous and papilliform patterns. Islets of smaller, lightly pigmented cells arrowed. Haematoxylin and eosin

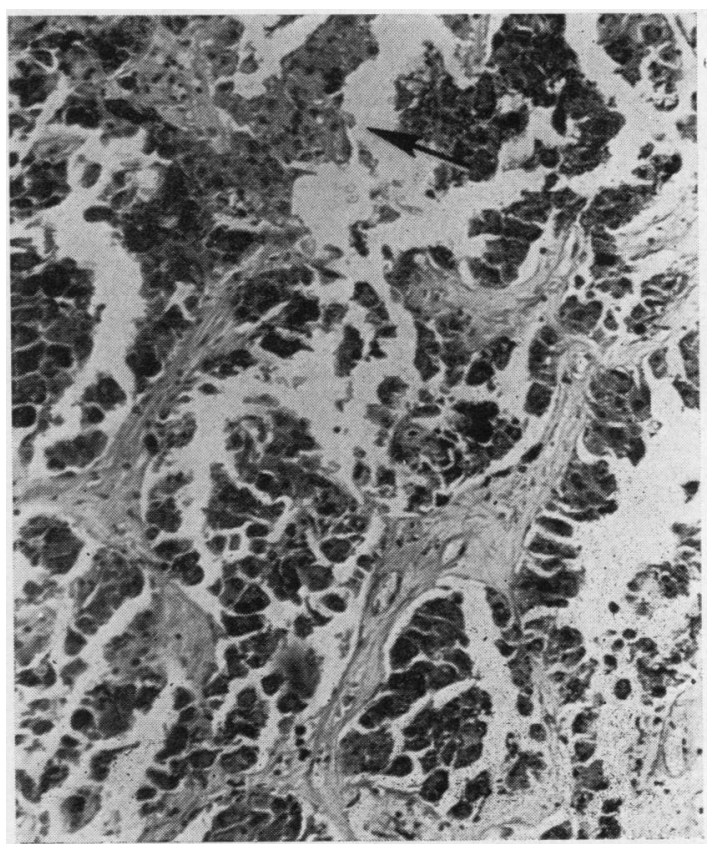

FIG. 5 $\times 125$.

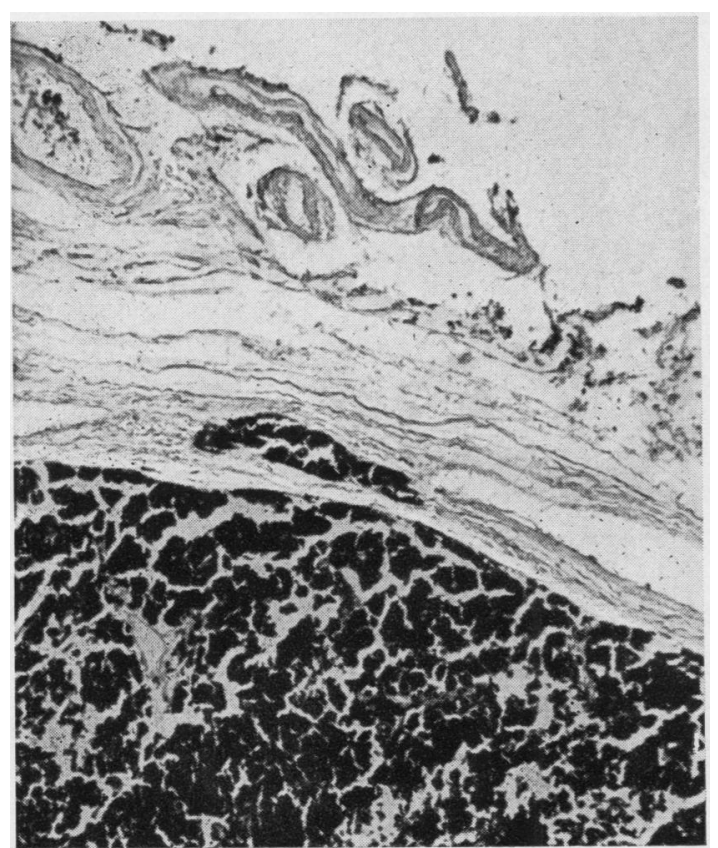

FIG. 4 Mallory trichrome $\times 50$.

FIG. 2. Chromophobe adenoma (a) at right. Pigmented tumour (b) bottom left. Atrophic anterior lobe tissue (c) between .

FIG. 3. Chromophobe adenoma with pigmented cells arrowed. Mallory trichrome $\times 500$. 


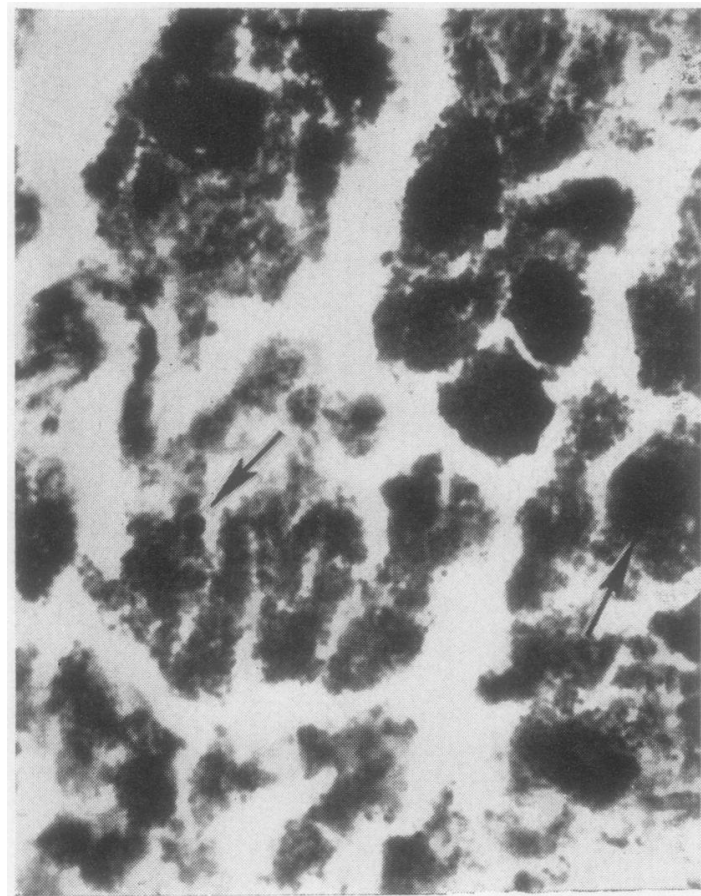

FIG. 6

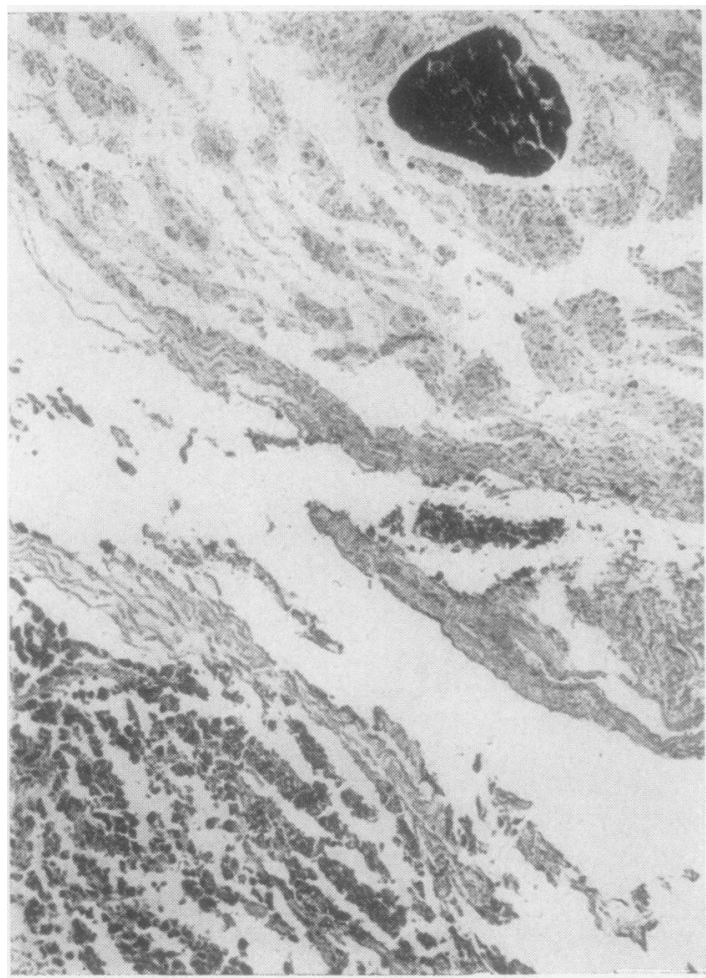

FIG. 7
FIG. 6. Heavily pigmented cells of variable shape showing discoid bodies (arrowed) and extrusion of pigment. Hae- matoxylin and eosin $\times 500$.

FIG. 7. Pars nervosa (above) showing pigmented tumouñ tissue. Main pigmented tumour at bottom left. Haematos $x y$ lin and eosin $\times 50$.

FIG. 8. Normal pars nervosa showing cells containing numerous melanin granules. Masson-Fontana $\times 560$. 
Bouton, 1958), and Gibson et al. agreed with Willis (1950) that the source of these tumours is the elongated pigment cells of the pia mater. While it could be postulated that the tumour described here originated from such cells of the pia mater, one of us has frequently observed the presence of similar pigment-containing cells in the pars nervosa of normal pituitary glands (Fig. 8). The staining reactions of the pigment in these cells are those of melanin. Kernohan and Sayre (1956) observe that 'often a golden brown pigment is scattered irregularly throughout the pars nervosa of the pituitary gland'. It seems that the tumour described by us may thus have two possible origins. Either it arose from the pigment cells of the pia mater or from the pigmentcontaining cells of the pars nervosa, but whatever its origin, from consideration of the facts we believe that the tumour was a primary melanoma and the cause of hypopituitarism in this patient.
We wish to thank Dr. J. B. Rennie, consultant physician. and Dr. J. C. Dick, consultant pathologist, for permission to publish this case. We are also grateful to Mr. P. S. Waldie for the illustrations and photographs.

\section{REFERENCES}

Anderson, W. A. D. (1953). Pathology, 2nd ed., p. 967. Mosby, St. Louis.

Biggart, J. H. (1961). Pathology of the Nervous System, 3rd ed., p. 334 Livingstone, Edinburgh.

, and Dott, N. M. (1936). Brit. med. J., 2, 1153.

Bouton, J. (1958). J. clin. Path., 11, 122.

Gibson, J. B., Burrows, D., and Weir, W. P. (1957). J. Path. Bact., $74,419$.

Kernohan, J. W., and Sayre, G. P. (1956). Tumors of the Pituitary Gland and Infundibulum. Atlas of Tumor Pathology. Section 10 , Fascicle 36, p. 11. Armed Forces Institute of Pathology, Washington.

Pearse, A. G. E. (1953). Histochemistry Theoretical and Applied p. 479. Churchill, London.

Willis, R. A. (1950). Principles of Pathology, p. 564. Butterworth, London.

(1959). In Modern Trends in Pathology, edited by D. H. Collins, p. 117. Butterworth, London. 